\title{
Effect of feeding range plants with or without Moringa oleifera on growth performance of Sudanese Desert Rams
}

\author{
I. Bushara ${ }^{1 \star}$, Sawsan F. A. Salih ${ }^{2}$ and Muna, M. M. Ahmed ${ }^{2}$ \\ ${ }^{1}$ Department of Animal Production. Faculty of Natural Resources and Environmental Studies, University of Kordofan El- \\ Obied, Sudan. \\ ${ }^{2}$ Institute of Environmental Studies, University of Khartoum. Sudan. \\ *Corresponding author. Email: bushara3030@yahoo.com
}

Copyright @ 2017 Bushara et al. This article remains permanently open access under the terms of the Creative Commons Attribution License 4.0, which permits unrestricted use, distribution, and reproduction in any medium, provided the original work is properly cited.

Received 11th January, 2017; Accepted 16th February, 2017

\begin{abstract}
Twelve growing Sudanese desert rams age between 4 to 5 months with average weight of $12.10 \pm 0.5$ were used to evaluate the effect of feeding Moringa oleifera on feed intake, weight gain and feed conversion ratio in a fattening study comprising of three experimental diets (mixture of range plants (RP), Moringa oleifera pods, stems and leaves (MPSL), and RP + MPSL). The rams were randomly assigned to three dietary treatments with four rams per treatment in a completely randomized desiged (CRD). The results revealed that animals on diet one (mixture of range plants) recorded the highest mean feed intake of $104.48 \mathrm{~g} /$ day as compared to the other treatments. Total body weight ranged from $3.3 \mathrm{~kg}$ in animals fed MPSL to $7.1 \mathrm{~kg}$ in animals fed mixture of RP + MPSL. Feed conversion ratio ranged from ranged from 0.039 to 0.082 . Therefore, animals on diet three $(R P+M P S L)$ were significantly $(P<0.01)$ better when compared to those on RP or MPSL in terms of performance. It was concluded that, diets containing mixture of range plants + Moringa oleifera pods, stems and leaves supported better growth performance signifying that inclusion of MPSL in fattening rams diet significantly $(\mathrm{P}<0.05)$ reduced feed intake, improved weight gain and feed conversion ratio.
\end{abstract}

Key words: Growth performance, Moringa oleifera, rams, range plants.

\section{INTRODUCTION}

The livestock sector plays a significant economic role in most developing countries, and is essential for the food security of the populations (Pattison et al., 2007). The productivity of farm animals in most tropical countries is generally low, mainly due to poor quality and inadequate feeds. The rangelands are of importance to traditional livestock rearers confined to the semi-desert, low rainfall, savannah, and the northern fringes of the high rainfall areas of Sudan (Dagish, 2005). In the semi-desert, the plant cover comprises a mixture of grasses and herbaceous plants intermingled with acacia trees and shrubs representing the main grazing areas for camels and sheep (Dagish, 2005). Previous records showed that the range carrying capacity is not balanced with livestock feed requirements (Bushara and Abu Nikhaila, 2012). There is therefore a gap between current rangeland production and the actual animal requirements. In such situations, the available grazing area is not generally sufficient to meet the maintenance requirements of such animals, at least for parts of the year (Aregheore, 2002).

The animals of most pastoralists in Khartoum state suffer from lack of feeds especially during the dry season, which makes them to move from one place to another in search of feeds and water all year round for their animals (Darrage, 1992).

Moreover, conventional feed resources (such as grains, cereals, legumes, etc.) for animal production are scarce and highly expensive in many parts of the world. Thus the need to search for alternative feed resources that may have valuable components in livestock diets (SzumacherStrabel et al., 2011; Zhou et al., 2012). The use of tree parts as alternative feed resources for ruminant livestock is becoming increasingly important in many parts of the tropics and sub-tropics (Silanikove, 2000; Melesse et al., 
2009). In fact, trees and shrubs are increasingly recognized as important components of animal feeding, particularly as suppliers of protein especially in harsh environmental conditions (Melesse et al., 2009).

Trees are used for a variety of purposes in both cropped lands and in livestock grazing systems. Traditionally, farmers on dry land of Africa have developed a wide range of agro-forestry and soil conservation strategies to adapt their crops and livestock production systems to the marginal condition (Mbwambo, 2004). The challenges in using forage as source of feed for animals are estimating its availability and intake and determining whether or not the forage can supply adequate nutrients for maintenance, growth, reproduction and lactation (Kakuru et al., 2004). Livestock owners traditionally use tree leaves, twigs, forbsbrowse plants and creepers for feeding animals. Besides the leaves, the extensive use of the flowers, pods and seeds of some trees have always played a significant role as feed supplements in livestock feeding (Sutherland et al., 1990).

Present knowledge on the potential value of fodder trees and shrubs together with their diversity; indicate that these feed resources are extremely useful for feeding ruminant livestock. The demonstrable benefits are improved performance of animals and reduced cost of feeding (Devendra, 1992; Aregheore, 2002). Moringa (Moringa oleifera) trees are multi-purpose trees of economic importance with several industrial and feeding values (Babker and Abdalbagi, 2015). The traditional feeding systems, particularly in tribal areas, make maximum use of local resources like crop residues, tree leaves, pods, seeds etc. (Pradhan et al., 1991); which led to improve animal production and reduce animal mortality. The present study was therefore designed to evaluate the effect of feeding Moringa oleifeira and mixture of range plants on the growth performance of Sudanese desert rams.

\section{MATERIALS AND METHODS}

This study were conducted in Omdurman area (Umbada locality, longitudes $15.7^{\circ} \mathrm{N}$, Latitudes $34.4^{\circ} \mathrm{E}$ and altitudes $1402 \mathrm{~m}$ above sea levels) of Khartoum state. The annual rain fall is 200 to $400 \mathrm{~mm}$, and the temperature range is 17 to $20^{\circ} \mathrm{C}$ in the winter and 30 to $48^{\circ} \mathrm{C}$ in the summer. The pastoralists in the area raise cattle, goats and sheep (7.7 million heads), moving all the year searching for ranges, fodder and water. The areas is occupied by some sedentary tribes with ownership of land and raising small number of animals cattle utilizing the nearby annual low quality pastures and browse trees.

\section{Experimental animal's management and diets}

Twelve (12) rams of Sudanese sheep rams were used in this experiment, with ages 9 to 12 months and weights ranging from 17 to $21 \mathrm{~kg}$. All animals were treated with the necessary medication against endo-and ectoparasites (AGVET, USA $1.0 \mathrm{ml} / 50 \mathrm{~kg}$ body weight subcutaneously Ivomec super drench) and vaccinated against Anthrax and Hemorrhagic Septicemia. The animals were ear tagged, weighed and divided into three groups, each group with 4 rams ; group one, is mixture of range plants (MRP), group two is moringa pods stem and leave $(\mathrm{M})$ and group three is mixture of Moringa leaves and range plants (M+MRP) as $50 \%$ to $50 \%$. Feeds were offered to rams at ad libitum. Each group consistent of four rams and fed individual and was kept in separate enclosures constructed from iron bars and wire, and equipped with water troughs. They were gradually introduced to the new feeds for a preliminary period of 7 days. Live weights of each animal were recorded at the start of experiment, then every two weeks until the end of the experiment in three months using spring balance. The animals were weighed in the morning.

\section{Statistical analysis}

The data were statistically analyzed according to complete block randomized design. Multiple range tests were used to compare the means using Statistical Package for the Social Sciences, software package (SPSS, 1999).

\section{RESULTS}

\section{Effect of Moringa on body weight gain and conversion feed ratio}

Sheep fed plants under study showed increase in body weight. The mean gain of the body was $4.7 \mathrm{Kg}$ for the group fed range species, $3.3 \mathrm{Kg}$ for the group fed moringa and 7.1 for the one fed $(M+R)$ (Table 1). The FCR for the group fed $(M+R)$ was 0.082 , followed by the group fed range species 0.044 and the one fed the moringa was 0.039 . There were significant increases obtained when feeding a mixture of range species $(P \leq 0.05)$ and when feeding the mixture plus moringa $(P \leq 0.05)$ as shown in Table 1 and Figure 1.

\section{Effect of Moringa on final body weight and growth rate}

The effect of feeding of different feeds on body weight gain and growth were summarized in Table 2. Feeding mixture of range plant with Moringa showed significant $(P$ $\leq 0.001$ ) effect. Also feeding mixture of range land plants significantly $(P \leq 0.005)$ affect growth rate of the rams better than feeding moringa alone.

\section{DISCUSSION}

Fodder trees and shrubs have always played a significant role in feeding domestic animals. In fact, trees and 
Table 1. Body weight gain $(\mathrm{kg})$ and Food conversion ratio for sheep fed plants.

\begin{tabular}{lccc}
\hline Groups of animals & Body weight gain $\mathbf{( k g )}$ & Mean feed intake(g) & FCR $^{\star}$ \\
\hline Group one (MRP) & 4.7 & 104.48 & 0.044 \\
Group two (M) & 3.3 & 84.14 & 0.082 \\
Group three (MRP+M) & 7.1 & 86.96 & 0.039 \\
\hline
\end{tabular}

${ }^{*} \mathrm{FCR}=$ feed conversion ratio.

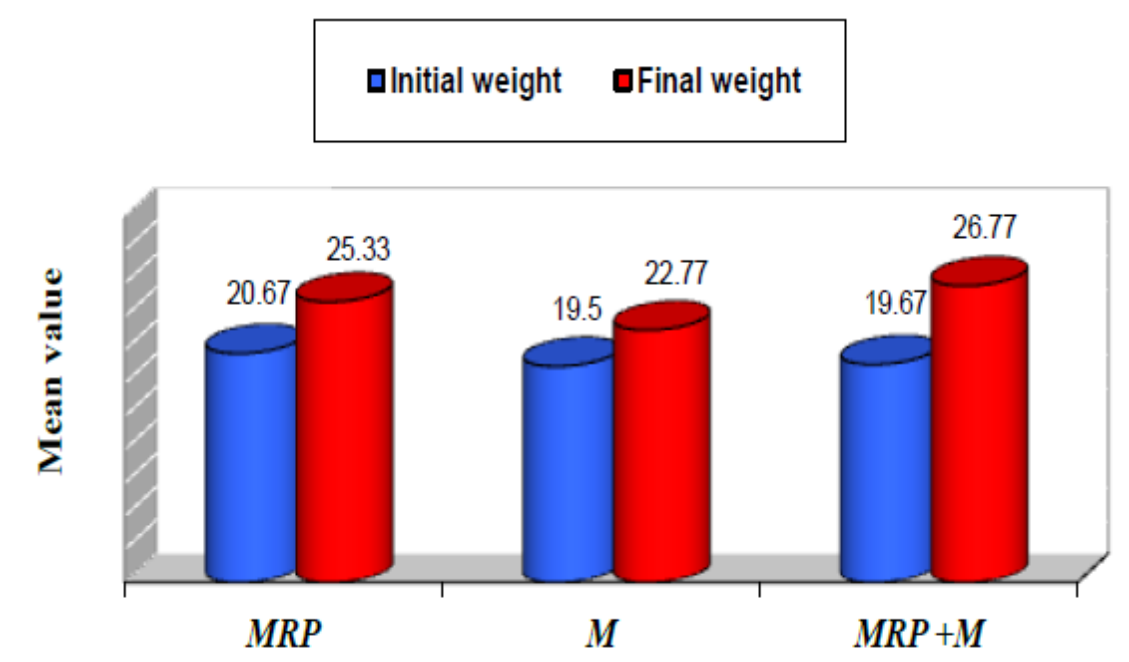

Figure 1. Initial and final body weights $(\mathrm{kg})$ for sheep fed plants under study.

Table 2. Initial and final body weights (kg) for sheep fed plants under study.

\begin{tabular}{lcccc}
\hline Groups of animals & Initial weight & Final weight & t value & p value \\
\hline Group one (MRP) & $20.67 \pm 0.58$ & $25.33 \pm 0.76$ & -6.424 & $0.023^{\star}$ \\
Group two (M) & $19.50 \pm 2.18$ & $22.77 \pm 3.87$ & -3.287 & $0.081 \mathrm{NS}$ \\
Group three (MRP+M) & $19.67 \pm 1.53$ & $26.77 \pm 0.68$ & -14.393 & $0.005^{\star \star}$ \\
\hline
\end{tabular}

$\mathrm{NS}=$ not significant; ${ }^{*}=$ significant at $\mathrm{P} \leq 0.05=;{ }^{* *}=$ significant at $\mathrm{P}<0.01$.

shrubs are increasingly recognized as important components of animal feeding, particularly as suppliers of protein, especially in harsh environmental conditions (Aregheore, 2002). Significant gains in animals' weights were observed when fed a mixture of range plants, but better gains were obtained when Moringa oleifera shoots were added to the mixture. Similarly the potential of agro forestry in supplying animals with high quality feeds has been recognized by many authors (Makkar and Becker, 1997; Fuglie, 2001; Maurício et al., 2008; Sanchita et al., 2017).

It was also shown that by planting a leguminous tree species in between rows of the grass, the nutritive value of the grass can be increased, improving livestock production (Harsh et al, 2003). A study in Fiji reports significant weight gain over traditional fodder when $50 \%$ of fodder contained moringa. Animals given fodder with $80 \%$ moringa in the Fijian study showed lower weight gain than animals on $50 \%$ moringa fodder (Aregheore,
2002). The traditional feeding systems, particularly in tribal areas, make maximum use of local resources like crop residues, tree leaves, pods, seeds, etc. (Pradhan et al., 1991). Many studies led to the development of methods of assessing the nutritive value of feeds and standardizing the feeding of animals according to their chemical composition. A study on the grazing behavior of goats; diet selection, nutritive value, digestibility of range plant and body gained at flowering and seed setting stage showed that the flowering stage was the best for goat in term of feed intake, dry matter digestibility and body weight gain (Abdel Moniem et al., 2013). Also in vitro gas production of Trifolium angustifolium hay showed that wild Trifolium angustifolium harvested even at the seeding stage, offered considerable potential as medium quality forage for ruminant animals during the winter period (Ademk and Canbolat, 2010). It has been stated that the leaves, shoots and twigs of legume/browse plants can help overcome the nutritional 
constraints of tropical grass species that are low in nutritive quality. (Mandal, 1997) and play an especially important role in improving dietary protein (Aregheore et al., 1998). Generally Moringa leaves are also a good protein source that is a convenient substitute of some meals (soybean and rapeseed) for ruminants, and they are able to improve the microbial protein synthesis in the rumen (Soliva et al., 2005).

\section{Conclusion and Recommendation}

It can be concluded that based on weight gained, farmers could include mixtures of range plants and Moringa oleifera pods, stems and leaves up to $50: 50 \%$ in the diet of Sudanese rams for optimum growth performance without deterimental effects on the animals. Mixture of range plants and Moringa oleifera could help small and medium-scale farmers overcome shortages of good quality feeds and therefore improve and sustain their livestock production.

\section{CONFLICT OF INTEREST}

The authors declare that they have no conflict of interest.

\section{REFERENCES}

Abdel Moniem, M. A., El hag, A., Bushara, I., Eisa, M. O., \& Ishag, I. A. (2013). Effect of plant maturity stage on digestibility and distance walked for diet selection by goat at north Kordofan State, Sudan. Global Journal of Animal Scientific Research, 1(1), 1-6.

Ademk, k., \& Canbolat, O. (2010). Determination of nutritive value of wild narrow-leaved clover (Trifolium angustifolium) hay harvested at three maturity stages using chemical composition and in vitro gas production. Tropical Grasslands, 44, 128-133.

Aregheore E M., Makkar, H. P. S., \& Becker, K. (1998). Feed value of some browse plants from the Central Zone of Delta State, Nigeria. Tropical Science, 38, 97-104.

Aregheore, E. M. (2002). Intake and digestibility of Moringa oleifera-batiki grass mixtures by growing goats. Small Ruminant Research, 46, 23-28.

Babker, E. A., \& Abdalbagi, Y. M. (2015). Effect of feeding different levels of Moringa Oleifera leaves on performance, haematological, biochemical and some physiological parameters of Sudan Nubian goats. Online Journal of Animal and Feed Research, 5(2), 50-61.

Bushara, I., \& Abu Nikhaila, M. M. A. A. (2012). Productivity Performance of Taggar Female Kids under Grazing Condition. Journal of Animal Production Advance, 2(1), 7479.

Dagish, Y. M. A. (2005). Range and Pasture Book. Dar Aziz, Khartoum, Sudan.Pp. 4-7.

Darrage, A. E. (1992). Evaluation of animal feed source under the umbrella of the National Comprehensive Strategy, Arabic Ed. In: Molasses workshop, Ministry of Agriculture Khartoum State, Khartoum, Sudan.

Devendra, C. (1992). Nutritional potential of fodder trees and shrubs as protein sources in ruminant nutrition. Legume trees and other fodder trees as protein sources for livestock.
Proceedings of the FAO Expert Consultation held at the Malaysian Agricultural Research and Development Institute (MARDI) in Kuala Lumpur, Malaysia.

Harsh, L. N., Khan, H. A., Bohra, M. D., \& Tewari, J. C. (2003). Growth performance and gum production of Acacia senegal in different landforms in hot arid zone of India. Journal of Non-timber Forest Products, 10, 1-7.

Makkar, H., \& Becker, K. (1997). Nutrients and antiquality factors in different morphological parts of the Moringa oleifera tree. Journal of Agricultural Science, 128, 311-332.

Mandal, L. (1997). Nutritive value of tree leaves of some tropical species for goats. Small Ruminant Research, 24, 95105.

Maurício, R. M., Sousa, L. F., Moreira, G. R., Reis, G. L., \& Gonçalves, L. C. (2008). Silvopastoral systems as a sustainable alternative to animal production in the tropics. Opportunities and challenges for smallholder ruminant systems in Latin America: resource management, food safety, quality and market access, 187-199.

Mbwambo, L. (2004). Status of Agroforestry in arid and semiarid areas of Tanzania. Paper presented at the ICRAF Dryland Agroforestry Workshop, 1-3 September.

Melesse, A., Bulang, M., \& Kluth, H. (2009). Evaluating the nutritive values and in vitro degradability characteristics of leaves, seeds and seedpods from M. stenopetala. Journal of Science and Food Agriculture, 89, 281-287.

Kakuru, W., Okia, C., \& Okorio, J. (2004). Uganda drylands agroforestry strategy. Paper presented at the ICRAF Dryland Agroforestry Workshop, 1-3 September.

Pattison, J., Drucker, A. G., \& Anderson, S. (2007). The cost of conserving livestock diversity? Incentive measures and conservation options for maintaining indigenous Pelon pigs in Yucatan, Mexico. Tropical Animal Health and Production, 39(5), 339-353.

Pradhan, P. K., Jape, A. S., \& Rangnekar, L. (1991). Traditional livestock management \& feeding systems in tribal ares of Gujarat and Rajasthan. Paper presented at International Workshop on Feeding of Ruminants on Fibrous Crop Residues. National Dairy Research Institutes, Karnal, India.

Sanchita, P., Tanmoy, G., \& Indranil, B. (2017). "Miracle tree" Moringa oleifera its nutritive importance and safety efficacy: A review. Indian Journal of Biology (in press).

Silanikove, N. (2000). The physiological basis of adaptation in goats in harsh environments. Small Ruminant Research, 35, 181-193.

Soliva C., Kreuzer, M., Foidl, N., Foidl, G., Machmüller, A., \& Hess, H. (2005). Feeding value of whole and extracted Moringa oleifera leaves for ruminants and their effects on ruminal fermentation in vitro. Animal Feed Science and Technology, 118, 47-62.

Sutherland, J. P., Folkard, G. K., \& Grant, W. D. (1990). Natural coagulants for appropriate water treatment: a novel approach, Waterlines, 4, 30-32.

SPSS (1999). Statistical Package for Social Sciences, Ver.10.0. Chicago: SPSS Inc.,

Szumacher-Strabel, M., Zmora, P., Roj, E., Stochmal, A., PersKamczyc, E., Urbańczyk, A., Oleszek, W., Lechniak, D., \& Cieślak, A. (2011). The potential of the wild dog rose (Rosa canina) to mitigate in vitro rumen methane production. Journal of Animal Feed Science., 20, 285-299.

Zhou, B., Meng, Q. X., Ren, L.P., Shi, F.H., Wei, Z., \& Zhou, Z. M. (2012). Evaluation of chemical composition in situ degradability and in vitro gas production of ensiled and sundried mulberry pomace. Journal of Animal Feed Science., 21, 188-197. 